JURNAL PENA INDONESIA

Jurnal Bahasa Indonesia, Sastra, dan Pengajarannya

Volume 1, Nomor 2, Oktober 2015

ISSN: 22477-5150

\title{
KETERBACAAN TEKS DALAM BUKU “BAHASA INDONESIA WAHANA
}

\section{PENGETAHUAN"}

\author{
Ariesta Bagus Pramuwibowo \\ IAIN Tulungagung \\ Email: cerpen.sma@gmail.com
}

\begin{abstract}
Abstrak
Keterbacaan teks dalam buku "Bahasa Indonesia Wahana Pengetahuan" revisi pertama (BIWPrp) pada Kurikulum 2013 belum pernah diteliti dari segi kualitas teks dan pengetahuan pembaca, padahal teks sangat penting dalam proses pembelajaran berdasarkan kurikulum tersebut. Sebab, teks berbahasa Indonesia merupakan teks model bagi mata pelajaran lain. Oleh karena itu, harus dianalisis tingkat keterbacaan teks dalam buku tersebut. Penelitian ini berjenis kuantitatifkualitatif dengan metode deskriptif. Selain itu, ada beberapa hasil penelitian ini. Pertama, tingkat keterbacaan teks dalam buku tersebut mudah, yakni 88\%, berdasarkan ciri-ciri kalimat efektif. Kedua, tingkat keterbacaan teks dalam buku itu sulit, yakni 15\%, berdasarkan pengetahuan awal pembaca tentang topik teks. Ketiga, level keterbacaan teks dalam buku tersebut cocok untuk kelas 7, 8, dan 9. Keempat, tingkat keterbacaan teks dalam buku itu sulit, yakni 13\%, berdasarkan kontrol kosakata yang dipengaruhi oleh pengetahuan kebahasaan siswa kelas VII.
\end{abstract}

Kata Kunci: tingkat keterbacaan teks, kalimat efektif, tes asosiasi kata, grafik fry, tes cloze.

\begin{abstract}
The readability text in book "Bahasa Indonesia Wahana Pengetahuan" first revision (BIWPrp) in the Curriculum book 2013 had never been researched before reviewable from text quality and reader knowledge, besides that the text was very important in learning proceeding based on curriculum 2013. Because, the text Indonesian was model text for any subject. Therefore, it must be analyzed the level of readability text of book. This research diversiformed quantity-quality with descriptive method. Moreover, there were research result. First, the level of readability text was easy, $88 \%$, based on the traits of effective sentence. Second, the level of readability text was difficult, 15\%, based on the early knowledge of reader about the topic text. Third, the level of readability text was suitable for 7,8 , and 9 grades. Fourth, the level of readability text was difficult, 13\%, based on the vocabularies control what clouted by the languagetion knowledge of VII grade student.
\end{abstract}

Keywords: level of readability text, effective sentence, association word test, fry graph, cloze test. 
Ariesta Bagus Pramuwibowo, Keterbacaan Teks dalam Buku...(hal. 240 - 259)

\section{PENDAHULUAN}

Kurikulum 2013 masih menjadi dilematika hingga saat ini. Terutama, buku yang sampai saat ini belum terdistribusi dengan tepat dan isi yang belum terpahami oleh guru dan siswa, padahal buku model sudah dicetak dan distribusikan sejak awal 2013. Satu di antara buku model tersebut adalah buku "Bahasa Indonesia Wahana Pengetahuan" untuk kelas VII (Permendiknas Nomor 71 Tahun 2013). Pada 2014, buku tersebut direvisi. Akan tetapi, masih banyak guru dan siswa yang mengeluh. Oleh karena itu, buku tersebut harus dikaji dari kualitas buku. Instrumen yang digunakan sebagai alat untuk mengidentifikasi buku pelajaran bahasa dan sastra Indonesia (BSI): a) materi, b) penyajian, c) bahasa dan keterbacaan, serta d) grafika (Pusat Perbukuan Nasional, 2003:2).

Buku tersebut belum dianalisis berdasarkan keterbacaan yang dikaitkan dengan kebahasaan. Pada penelitian-penelitian sebelumnya, penelitian keterbacaan menggunakan kontrol kosakata, formula keterbacaan, leksis, dan gramatika secara terpisah. Hal itu berbeda dengan penelitian ini. Sebab, penelitian ini mengombinasikan beberapa cara mengukur tingkat keterbacaan teks dalam buku BIWPrp.

Cara tersebut yaitu penilaian subjektif, tanya jawab, formula keterbacaan, grafik dan carta, serta tes Cloze (Gilliland, 1972). Dari lima cara tersebut, hanya empat cara yang digunakan dalam penelitian ini. Empat cara tersebut adalah penilaian subjektif, tanya jawab, formula keterbacaan, dan tes Cloze. Hal tersebut disebabkan ada dua cara yang hampir sama, yakni formula keterbacaan serta grafik dan carta. Berdasarkan hal itu, tujuan penelitian ini adalah untuk mengukur keterbacaan teks dalam buku BIWPrp.

Untuk mencapai tujuan tersebut, digunakan instrumen pengukuran keterbacaan. Pertama, instrumen yang terkait dengan penilaian subjektif adalah penganalisisan kalimat dalam teks itu berdasarkan isi yang mudah dipahami oleh siswa. Hal tersebut sesuai ciri-ciri kalimat efektif. Kalimat efektif adalah kalimat 
yang memiliki kemampuan untuk menimbulkan kembali gagasan-gagasan pada pikiran pendengar atau pembaca seperti apa yang ada dalam pikiran atau perasaan pembicara atau penulis (Ningsih dkk., 2007:94). Menurut Ningsih dkk. (2007:94), kalimat efektif berciri-ciri a) kesepadanan struktur, b) keparalelan, c) ketegasan, d) kehematan, e) kecermatan, f) kepaduan, dan g) kelogisan.

Kedua, instrumen yang terkait dengan tanya jawab adalah tes asosiasi kata. Isian tes tersebut didasarkan pada pengetahuan awal pembaca tentang topik. Pengetahuan awal pembaca berpengaruh terhadap kemampuan pembaca memahami teks yang akan dibaca. Oleh karena itu, digunakan tes asosiasi kata. Tes asosiasi kata dapat digunakan untuk mengukur topik yang akrab bagi pembaca (dalam Zakulak dan Samuels, 1988:35).

Ketiga, instrumen yang terkait dengan formula keterbacaan adalah Grafik Fry. Grafik tersebut didasarkan pada panjang-pendek kata dan tingkat kesulitan yang ditandai oleh jumlah (banyak/sedikitnya) suku kata yang membentuk setiap kata dalam wacana tersebut (Muchlisoh, 1996:170).

Keempat, instrumen yang digunakan adalah tes Cloze. Tes tersebut didasarkan pada kontrol kosaka yang dipengaruhi oleh pengetahuan kebahasaan pembaca. Dalam tes tersebut, ada tiga faktor utama, yakni pemilihan teks, prosedur penskoran, dan taraf perumpangan. Taraf perumpangan juga didasarkan pada unsur kebahasaan yang harus dikuasai siswa kelas VII.

\section{METODE}

Penelitian ini berjenis kuantitatif-kualitatif dengan metode deskriptif. Dalam penelitian ini, ada tiga sumber data yang digunakan. Pertama, sumber data yang digunakan adalah lima teks yang terdapat dalam buku BIWPrp, yakni teks Biota Laut, Tari Saman, Remaja dan Pendidikan Karakter, Gempa Bumi, serta Candi Prambanan. Teks tersebut mewakili lima jenis teks yang harus dipelajari siswa, yakni teks laporan hasil observasi, tanggapan deskriptif, eksposisi, eksplanasi, dan cerita pendek. Kedua, sumber data yang digunakan 
Ariesta Bagus Pramuwibowo, Keterbacaan Teks dalam Buku...(hal. 240 - 259)

adalah pengetahuan awal siswa tentang topik. Ketiga, sumber data yang digunakan adalah pengetahuan kebahasaan siswa tentang kosakata yang mengisi kalimat rumpang. Instrumen yang digunakan untuk sumber data pertama adalah analisis kalimat berdasarkan ciri-ciri kalimat efektif dan Grafik Fry. Sumber data kedua menggunakan instrumen tes asosiasi kata. Sumber data ketiga menggunakan instrumen tes Cloze.

Dalam penelitian ini, lokasi penelitian ini adalah SMPN 1 Kemlagi, SMPN 2 Sooko, SMP Puri Swasta, dan SMP Swasta Islam Al-Khotimah. Selain itu, subjek penelitian ini adalah 80 siswa dari empat sekolah tersebut. Tiap sekolah 20 siswa. Dalam penelitian ini, digunakan dua teknik pengumpulan data. Pertama, teknik dokumentasi yang digunakan untuk mengumpulkan kalimat berdasarkan ciri-ciri kalimat efektif dam untuk mengumpulkan data berdasarkan panjang-pendek kata. Kedua, teknik tes asosiasi kata yang digunakan untuk mengumpulkan data berdasarkan pengetahuan awal pembaca tentang topik dan tes Cloze yang digunakan untuk mengumpulkan data berdasarkan kontrol kosakata yang dipengaruhi pengetahuan kebahasaan siswa.

Ada beberapa langkah untuk masing-masing teknik.

\section{Teknik Dokumentasi: Analisis Kalimat Efektif}

a. Pemilihan kalimat-kalimat yang terdapat dalam lima teks sampel.

b. Kalimat-kalimat tersebut dianalisis berdasarkan lembar analisis kalimat efektif yang sesuai dengan ciri-ciri kalimat efektif sebagai berikut.

c. Hasil analisis kemudian dimasukkan ke lembar skor kalimat.

d. Kalimat yang terdapat pada lembar skor kalimat diubah dengan ketentuan sebagai berikut.

1) Jika mendapat total skor 6/7, kalimat itu merupakan kalimat efektif. Oleh karena itu, kalimat itu bernilai 1 (satu).

2) Jika mendapat total skor $\leq 5$, kalimat itu merupakan kalimat tidak efektif. Oleh karena itu, kalimat itu bernilai 0 (nol). 
Teknik Dokumentasi: Grafik Fry

a. Penghitungan penetapan kata ke-1 s.d. 100.

b. Penghitungan jumlah suku kata (kata ke-1 s.d. 100) tiap teks.

c. Penghitungan jumlah kalimat (kata ke-1 s.d. 100).

\section{Teknik Tes Asosiasi Kata}

a. Persiapkan instrumen berdasarkan topik lima teks tersebut.

b. Peneliti dan pihak sekolah berkoordinasi untuk menentukan waktu yang tepat untuk pelaksanaan tes, baik tes asosiasi kata maupun tes Cloze.

c. Waktu yang disepakati harus pagi atau jam pertama. Selain itu, pengawas tes tersebut adalah guru yang mengajar di jam tersebut.

d. Peserta tes/siswa kelas VII (sekolah sampel) diberi tahu tentang petunjuk pengerjaan tugas tersebut oleh pengawas yang dibantu peneliti. Aktivitas pengawas tes diamati peneliti.

e. Setiap lembar tes harus diisi tiap siswa dengan pengetahuan yang dia ketahui (tidak boleh ada sontekan).

f. Setiap isian harus diisi oleh siswa/peserta.

g. Tiap-tiap siswa diberi waktu 3 menit untuk mengerjakan tiap lembar tes asosiasi kata.

h. Jika ada siswa yang bekerja sama, hasil tes siswa tersebut tidak diakui. Oleh karena itu, peneliti akan mengganti siswa tersebut dengan siswa dari kelas lain.

i. Setelah 15 menit, semua lembar tes yang sudah terisi dikumpulkan ke pengawas.

j. Setiap lembar tes yang sudah terkumpul diserahkan ke peneliti.

k. Setiap lembar tes tersebut dianalisis berdasarkan jawaban yang disesuaikan dengan isi teks yang sebenarnya (kesesuaian/ketidaksesuaian berdasarkan pemahaman tiap jawaban siswa yang dibandingkan dengan pemahaman isi teks sampel). 
Ariesta Bagus Pramuwibowo, Keterbacaan Teks dalam Buku...(hal. 240 - 259)

m. Setiap jawaban yang sesuai diberi skor satu, sedangkan setiap jawaban yang tidak sesuai diberi skor nol.

\section{Teknik Tes Cloze}

a. Taraf Perumpangan

1) Kalimat pertama dan terakhir tidak diubah/tidak ada kata yang dihilangkan. 2) Jumlah kata yang dihilangkan lima puluh.

3) Kata yang dihilangkan tidak boleh berdampingan, minimal tersekat satu kata.

4) Kata yang dihilangkan berdasarkan temuan unsur kebahasaan tiap teks. b. Pelaksanaan dan Penskoran 1) Tes Cloze dilakukan setelah tugas asosiasi kata.

2) Pengawas dan peneliti membagi setiap lembar tes Cloze kepada tiap-tiap siswa.

4) Pengawas menyampaikan hal yang harus dilaksanakan siswa, yakni siswa harus mengisi kekosongan dengan kata yang tepat.

5) Untuk mengisi satu lembar teks tersebut, peneliti memberi waktu 5 menit.

6) Hal itu dilaksanakan berulang-ulang sesuai jumlah teks, yakni lima belas teks.

7) Setelah 25 menit, pengawas dan peneliti mengumpulkan seluruh lembar yang sudah diisi siswa dalam satu amplop.

8) Setiap lembar tes yang sudah terkumpul diserahkan ke peneliti.

9) Setiap lembar tes tersebut dianalisis berdasarkan kesesuaian antara jawaban siswa dengan kunci jawaban.

10) Setiap jawaban yang sesuai diberi skor satu, sedangkan setiap jawaban yang tidak sesuai diberi skor nol.

Dalam penelitan ini, ada beberapa teknik analisis data.

\section{Data Berupa Jumlah Kalimat Efektif dan Tidak Efektif}


Data (nilai) yang berasal dari perubahan angka bedasarkan total skor dijumlah. Hasil penjumlahan dipersentasekan dengan cara membagi total nilai tersebut dengan jumlah kalimat tiap-tiap teks untuk menentukan keterbacaan tiap teks sampel. Setelah itu, seluruh nilai dijumlah. Hasil penjumlahan tersebut dipersentasekan dengan cara membagi seluruh nilai dengan seluruh kalimat dalam lima teks sampel.

\section{Data Berupa Skor Pengerjaan Tugas Asosiasi Kata}

Data yang berupa jumlah skor dari hasil pengerjaan siswa terbagi atas total skor tiap sekolah (tiap topik tes), persentase skor seluruh sekolah (tiap topik tes), serta persentase skor seluruh tes. Persentase skor seluruh sekolah (tiap topik tes) digunakan sebagai data acuan tingkat keterbacaan tiap teks sampel, sedangkan persentase skor seluruh tes digunakan sebagai data acuan tingkat keterbacaan teks dalam buku BIWPrp.

a. Untuk menghasilkan total skor tiap sekolah (tiap topik tes), dijumlahkan skor tiap peserta (tiap sekolah).

b. Untuk menghasilkan persentase skor seluruh sekolah (tiap topik tes), digunakan rumus sebagai berikut.

$$
\mathrm{PS}^{1}=\frac{\varepsilon \mathrm{ES}^{1}}{960} \times 100 \%
$$

Keterangan:

$\mathrm{PS}^{1}=$ Persentase skor seluruh sekolah (tiap topik tes)

$\mathcal{E T S}^{1}=$ Total skor seluruh sekolah (tiap topik tes)

c. Untuk menghasilkan persentase skor seluruh tes digunakan rumus sebagai berikut.

$$
\mathrm{PS}^{2}=\frac{\varepsilon \mathrm{TS}^{2}}{4800} \times 100 \%
$$

Keterangan:

$\mathrm{PS}^{2}=$ Persentase skor seluruh teks 
Ariesta Bagus Pramuwibowo, Keterbacaan Teks dalam Buku...(hal. 240 - 259)

$\varepsilon \mathrm{TS}^{2}=$ Total skor seluruh tes (lima topik tes)

\section{Data Berupa Jumlah Suku Kata dan Kalimat (Grafik Fry)}

Data yang berupa jumlah suku kata dikonversi terlebih dahulu (dikalikan 0,6) karena Grafik Fry sebenarnya untuk teks berbahasa Inggris, sedangkan teks sampel penelitian ini berbahasa Indonesia. Selanjutnya, jumlah suku kata dan kalimat digunakan sebagai dasar penentu titik temu di Grafik Fry.

\section{Data Berdasarkan Tes Cloze}

Data yang dihasilkan dari tes tersebut adalah skor hasil pengerjaan siswa kelas VII. Analisis data tersebut sebagai berikut.

a. Isian siswa dikoreksi benar/salah dengan mencocokkan isian tersebut dengan kunci jawaban. Setelah itu, dihitung jumlah benar dan jumlah salah. Setelah penghitungan tersebut, jumlah benar dibagi jumlah kunci jawaban lalu dikali 100.

b. Skor tiap siswa tersebut dijumlahkan lalu dibagi jumlah siswa berdasarkan judul teks.

c. Skor yang diperoleh seluruh siswa di tiap sekolah sampel berdasarkan judul teks dijumlahkan lalu dibagi jumlah siswa tiap sekolah.

d. Skor yang dihasilkan di langkah ke-3 seluruh sekolah sampel dijumlahkan lalu dibagi jumlah sekolah sampel, yakni empat.

e. Skor yang dihasilkan di langkah ke-4 tiap teks dijumlahkan lalu dibagi jumlah teks sampel, yakni lima.

f. Skor yang dihasilkan di langkah ke-5 menjadi acuan tingkat keterbacaan.

\section{HASIL DAN PEMBAHASAN}

Ada empat hasil utama yang terdeskripsikan dalam bab ini. Pertama, terdeskripsikan tingkat keterbacaan teks berdasarkan aspek kalimat yang efektif. 
Kedua, terdeskripsikann tingkat keterbacaan teks berdasarkan pengetahuan awal pembaca tentang topik teks. Ketiga, terdeskripsikan level keterbacaan teks berdasarkan panjang-pendek kata. Keempat, terdeskripsikan tingkat keterbacaan teks berdasarkan kontrol kosakata yang dipengaruhi oleh pengetahuan kebahasaan siswa kelas VII. Empat hal tersebut terdeskripsikan dan terpaparkan sebagai berikut.

\section{Keterbacaan Teks dalam Buku BIWPrp Berdasarkan Keefktifan Kalimat}

Berdasarkan analisis 99 kalimat dalam teks, terdapat 87 kalimat yang sesuai dengan ciri-ciri kalimat efektif dan 12 kalimat yang tidak sesuai dengan satu atau lebih ciri-ciri kalimat efektif. Jika kalimat tersebut adalah kalimat efektif, nilai kalimat itu ialah 1. Jika kalimat tersebut adalah kalimat tidak efektif, nilai kalimat itu ialah 0 . Oleh karena itu, total nilai dari seluruh teks sampel adalah 87. Berdasarkan total nilai dan jumlah kalimat, persentase total nilai tersebut sebagai berikut.

$$
\begin{gathered}
\text { Persentase total nilai }=\frac{\text { total nilai }}{\text { jumlah kalimat }} \times 100 \% \\
\text { Persentase total nilai }=\frac{87}{99} \times 100 \%
\end{gathered}
$$

Oleh karena itu, persentase total nilai tersebut adalah $88 \%$. Persentase tersebut disesuaikan dengan Tabel 1.1. Hasil penyesuaian menyatakan bahwa tingkat keterbacaan teks dalam buku BIWPrp adalah mudah. Maksudnya, siswa kelas VII mudah membaca teks dalam buku tersebut, khususnya siswa yang bersekolah di Kabupaten Mojokerto.

\section{Keterbacaan Teks dalam Buku BIWPrp Berdasarkan Pengetahuan Awal Pembaca tentang Topik Teks}

Total skor seluruh teks yang berasal dari peserta tes, yakni siswa SMP Negeri 1 Kemlagi, SMP Negeri 2 Sooko, SMP Puri Swasta, dan SMP Swasta Islam 
Ariesta Bagus Pramuwibowo, Keterbacaan Teks dalam Buku...(hal. 240 - 259)

Al-Khotimah, terdapat di Tabel 1.4. total skor tersebut menjadi acuan tingkat keterbaan teks yang terdapat dalam buku BIWPrp berdasarkan pengetahuan pembaca tentang topik teks.

Tabel 1.4

Skor Tes Asosiasi Kata Seluruh Tes

\begin{tabular}{|c|c|c|c|c|c|c|}
\hline \multirow{2}{*}{ Nomor } & \multirow{2}{*}{ Nama Sekolah } & \multicolumn{5}{|c|}{ Topik } \\
\cline { 3 - 7 } & SMPN 1 & BL & TS & RPK & GB & CCP \\
\hline 1 & Kemlagi & 60 & 30 & 22 & 50 & 5 \\
\hline 2 & SMPN 2 Sooko & 65 & 44 & 38 & 42 & 11 \\
\hline 3 & $\begin{array}{c}\text { SMP Puri } \\
\text { Swasta }\end{array}$ & 61 & 33 & 34 & 40 & 16 \\
\hline 4 & SMP Islam & 31 & 39 & 53 & 27 & 26 \\
\hline
\end{tabular}

Keterangan Singkatan:

BL : Biota Laut

TS : Tari Saman

RPK : Remaja dan Pendidikan Karakter

GB : Gempa Bumi

CCP : Cerita Candi Prambanan

Berdasarkan Tabel 1.4 diperoleh total skor tiap topik sebagai berikut.

1) Total skor topik Biota Laut adalah 217.

2) Total skor topik Tari Saman adalah 146.

3) Total skor topik Remaja dan Pendidikan Karakter adalah 147.

4) Total skor topik Gempa Bumi adalah 159.

5) Total skor topik Cerita Candi Prambanan adalah 58.

Berdasarkan lima data tersebut, total skor seluruh tes (ETS $\left.{ }^{2}\right)$ adalah 727. Setelah itu, total skor tersebut dimasukkan dalam rumus untuk menghasilkan persentase skor seluruh tes $\left(P S^{2}\right)$.

$\mathrm{PS}^{2}=\frac{\varepsilon \mathrm{ES}^{2}}{4800} \times 100 \%$

$P^{2}=\frac{727}{4800} \times 100 \%$ 
$\mathrm{PS}^{2}=0,15 \times 100 \%$

$\mathrm{PS}^{2}=15 \%$

Setelah itu, PS $^{2}$ disesuaikan dengan tingkat keterbacaan dalam Tabel 1.2. Dengan demikian, tingkat keterbacaan teks dalam buku BIWPrp berdasarkan pengetahuan awal siswa SMPN 1 Kemlagi, SMPN 2 Sooko, SMP Puri Swasta, dan SMPS Islam Al-Khotimah (sampel siswa dari sekolah terakreditasi A, baik sekolah sasaran Kurikulum 2013 maupun bukan, sekolah terakreditasi B, dan sekolah terakreditasi C) adalah sulit, yakni teks dalam buku tersebut kurang sesuai dengan siswa kelas VII yang bersekolah di Kabupaten Mojokerto.

\section{Keterbacaan Teks dalam Buku BIWPrp Berdasarkan Panjang-Pendek Kata}

Untuk mengukur level keterbacaan seluruh teks dalam buku BIWPrp digunakan hasil pembagian jumlah suku kata dan kalimat dalam teks sampel, yakni teks Biota Laut, Tari Saman, Remaja dan Pendidikan Karakter, Gempa Bumi, dan Candi Prambanan. Jumlah suku kata dan kalimat dalam teks-teks tersebut terdapat di Tabel 1.5 .

Tabel 1.5

Jumlah Suku kata dan Kalimat dalam Teks Sampel

\begin{tabular}{|c|c|c|c|}
\hline \multirow[b]{2}{*}{ No-mor } & \multirow[b]{2}{*}{ Judul Teks } & \multicolumn{2}{|c|}{ Jumlah } \\
\hline & & $\begin{array}{l}\text { Suku } \\
\text { Kata }\end{array}$ & Kalimat \\
\hline 1 & Biota Laut & 134,4 & 5,45 \\
\hline 2 & Tari Saman & 165,6 & 9,13 \\
\hline 3 & $\begin{array}{l}\text { Remaja dan } \\
\text { Pendidikan } \\
\text { Karakter }\end{array}$ & 156,6 & 6,88 \\
\hline 4 & Gempa Bumi & 141 & 6,40 \\
\hline 5 & Candi & 151,2 & 10,50 \\
\hline
\end{tabular}

250 | ISSN: 22477-5150 http://journal.unesa.ac.id/index.php/jpi 


\begin{tabular}{|l|l|l|l|} 
& Prambanan & & \\
\hline Total & 149,8 & 7,67 \\
\hline
\end{tabular}

Berdasarkan penyesuaian total jumlah suku kata dan kalimat (Tabel 1.5) dengan grafik, level keterbacaan teks dalam buku BIWPrp adalah 7, 8, dan 9. Dengan kata lain, teks dalam buku tersebut layak dibaca oleh siswa kelas VII, terutama siswa yang bersekolah di Kabupaten Mojokerto.

\section{Keterbacaan Teks dalam Buku BIWPrp Berdasarkan Kontrol Kosakata yang Dipengaruhi Pengetahuan Kebahasaan Siswa}

Berdasarkan tabel 1.6, total skor seluruh tes adalah 2.565. Skor tersebut menjadi data acuan tingkat keterbacaan teks dalam buku BIWPrp dengan cara membagi skor tersebut dengan total skor sebenarnya, yakni 20.000. Setelah itu, hasil pembagian dipersentasekan. Hasil presentasi disesuaikan dengan Tabel 1.3 untuk mengetahui tingkat keterbacaan teks dalam buku tersebut.

Berdasarkan uraian tersebut, hasil pembagian skor seluruh tes dengan total skor sebenarnya adalah 0,13 . Setelah itu, hasil tersebut dikali dengan angka 100\%. Hasil persentase tersebut adalah 13\%. Berdasarkan kesesuaian antara hasil persentase dengan Tabel 1.3, tingkat keterbacaan teks dalam buku BIWPrp adalah sulit, yakni teks dalam buku tersebut kurang sesuai dengan siswa yang bersekolah di SMP se-Kabupaten Mojokerto.

Tabel 1.6

Skor Seluruh Tes Cloze

\begin{tabular}{|l|l|l|}
\hline Nomor & Judul Tes Cloze & Skor \\
\hline 1 & Biota Laut & 343 \\
\hline 2 & Tari Saman & 203 \\
\hline 3 & Remaja dan Pendidikan & 417 \\
\hline
\end{tabular}




\begin{tabular}{|l|l|l|} 
& Karakter & \\
\hline 4 & Gempa Bumi & 1209 \\
\hline 5 & Candi Prambanan & 393 \\
\hline Total & & 2565 \\
\hline
\end{tabular}

\section{Keterbacaan Teks dalam Buku BIWPrp Berdasarkan Kualitas Teks dan Pengetahuan Pembaca}

Tingkat keterbacaan teks berdasarkan kualitas teks didasarkan pada kesesuaian teks dengan ciri kalimat efektif dan panjang-pendek kata. Berdasarkan dua hal tersebut ditemukan bahwa tingkat keterbacaan teks adalah mudah sehingga sesuai dengan level pembaca, yakni siswa kelas VII. Hal tersebut dibuktikan dengan persentase yang dihasilkan setelah membandingkan kalimat yang sesuai dengan ciri kalimat efektif dengan jumlah kalimat seluruh teks, yakni 88\%. Bukti yang lain adalah ketepatan level keterbacaan teks berdasarkan panjang-pendek kata (Grafik Fry), yakni 7, 8, dan 9.

Berbeda dengan hal itu, tingkat keterbacaan teks berdasarkan pengetahuan pembaca didasarkan pada pengetahuan awal pembaca tentang topik dan kontrol kosakata yang dipengaruhi oleh pengetahuan kebahasaan pembaca. Berdasarkan dua hal itu ditemukan bahwa tingkat keterbacaan teks adalah sulit. Hal tersebut dibuktikan dengan hasil tes asosiasi kata (tes yang didasarkan pada pengetahuan awal pembaca tentang topik), yaitu 15\%. Bukti yang lain didasarkan pada tes Cloze (tes yang didasarkan pada kontrol kosakata yang dipengaruhi oleh pengetahuan kebahasaan siswa), yaitu $13 \%$.

Tabel 1.7

Hasil Pengukuran Keterbacaan Teks

\begin{tabular}{|l|l|l|l|}
\hline \multirow{2}{*}{ Nomor } & Pengukur & \multicolumn{2}{|l|}{ Hasil } \\
\cline { 3 - 4 } 1 & Keterbacaan & Angka & Tafsiran \\
\hline \multirow{2}{*}{1} & $\begin{array}{l}\text { Penilaian Subjektif } \\
\text { (Kesesuaian dengan } \\
\text { Ciri Kalimat Efektif) }\end{array}$ & $87 \%$ & $\begin{array}{l}\text { Teks dalam buku tersebut mudah dibaca } \\
\text { dan dipakai ketika kegiatan belajar- } \\
\text { mengajar oleh siswa kelas VII karena ide }\end{array}$ \\
\hline
\end{tabular}

252 | ISSN: 22477-5150 http://journal.unesa.ac.id/index.php/jpi 


\begin{tabular}{|l|l|l|l|} 
& & & $\begin{array}{l}\text { kalimat dalam teks itu mudah dipahami } \\
\text { pembaca. }\end{array}$ \\
\hline 2 & $\begin{array}{l}\text { Tes Tanya Jawab (Tes } \\
\text { Asosiasi Kata) }\end{array}$ & $15 \%$ & $\begin{array}{l}\text { Teks dalam buku itu sulit dibaca dan } \\
\text { dipakai saat kegiatan belajar-mengajar } \\
\text { oleh siswa kelas VII karena isi dalam teks } \\
\text { tersebut berbeda (sulit) dengan } \\
\text { pengetahuan awal siswa tentang topik } \\
\text { teks tersebut. }\end{array}$ \\
\hline 3 & Formula (Grafik Fry) & $\begin{array}{l}7,8, \\
\text { dan 9 } 9\end{array}$ & $\begin{array}{l}\text { Teks dalam buku itu sebenarnya cocok } \\
\text { dengan siswa kelas VIII. Akan tetapi, teks } \\
\text { tersebut juga bisa dibaca oleh siswa } \\
\text { kelas VII yang akan ke kelas VIII dan } \\
\text { siswa kelas IX yang baru naik. Oleh } \\
\text { karena itu, siswa kelas VII sulit untuk } \\
\text { memahami teks tersebut. }\end{array}$ \\
\hline 4 & Tes Cloze & $13 \%$ & $\begin{array}{l}\text { Teks dalam buku tersebut sulit dibaca } \\
\text { dan dipakai saat kegiatan belajar- } \\
\text { mengajar oleh siswa kelas VII karena } \\
\text { kata dalam kalimat itu sulit dikontrol } \\
\text { oleh siswa kelas tersebut. }\end{array}$ \\
\hline
\end{tabular}

Dengan demikian, teks dalam buku BIWPrp sulit dibaca dan dipahami siswa kelas VII karena kualitas teks berdasarkan panjang-pendek kata dan pengetahuan siswa (awal serta pengontrolan kata) tergolong sulit bagi siswa tersebut.

\section{Diskusi Hasil Penelitian}

Dalam proses analisis, ada beberapa hal yang bisa didiskusikan lebih lanjut untuk penelitian selanjutnya. Diskusi tersebut sebagai berikut.

\section{Kohesi Gramatikal dalam Teks}

Dalam penelitian ini, penilaian subjektif dilakukan dengan cara menganalisis kalimat berdasarkan ciri-ciri kalimat efektif. Cara tersebut berbeda dengan cara yang dilakukan oleh Handayani. Handayani (2013) meneliti keterbacaan teks dengan cara menganalisis kalimat berdasarkan jenis, yakni kalimat sederhana, kalimat majemuk, dan kalimat majemuk bertingkat. Dia memfokuskan tingkat keterbacaan dari panjang kalimat (rata-rata jumlah kata 
per kalimat) yang didasarkan pada tiga jenis tersebut. Dia tidak menganalisis kohesi gramatikal dalam kalimat itu.

Berbeda dengan itu, untuk menentukan tingkat keterbacaan teks, penelitian ini menganalisis kalimat berdasarkan ciri-ciri kalimat efektif. Dari tujuh ciri tersebut, ada tiga ciri yang berhubungan dengan kohesi gramatikal, yakni penggunaan konjungsi intrakalimat di kesepadanan struktur, keparalelan, dan kepaduan. Berdasarkan hasil penelitian, penggunaan konjungsi intrakalimat ada tepat, tidak tepat, dan tidak perlu. Ada 51 kalimat yang konjungsi intrakalimatnya digunakan dengan tepat, 3 kalimat yang konjungsi intrakalimatnya digunakan tidak tepat, dan 2 kalimat yang konjungsi intrakalimatnya tidak perlu digunakan.

Konjungsi intrakalimat yang paling banyak ada adalah konjungsi penambahan, yakni kata "dan", yang juga menjadi satu di antara cara untuk menganalisis keparalelan dalam kalimat. Konjungsi tersebut berguna untuk menghubungkan bagian yang bersifat menambahkan informasi dan pada umumnya digunakan untuk merangkaikan dua proposisi atau lebih (Rani dkk., 2004:118).

\section{Tipe Bahasa dan Input Memengaruhi Tingkat Keterbacaan Teks}

Banyak faktor yang memengaruhi memori karangan bebas (Clark dan Clark, 1977:133). Dalam penelitian ini, karangan bebas yang dimaksud adalah topik yang berhubungan dengan teks Biota Laut, Tari Saman, Remaja dan Pendidikan Karakter, Gempa Bumi, serta Candi Prambanan sebelum pembaca, siswa kelas VII se-Mojokerto, membaca lima teks tersebut. Selain itu, Dick dan Carey (1990) menyatakan bahwa perlu adanya identifikasi tingkah laku awal/karakteristik siswa sebelum pembelajaran. Hal tersebut berkaitan dengan teks yang dibaca siswa harus sesuai dengan pengetahuan awal tentang topik tertentu.

\section{a. Tipe Bahasa}

254 | ISSN: 22477-5150 http://journal.unesa.ac.id/index.php/jpi 
Ariesta Bagus Pramuwibowo, Keterbacaan Teks dalam Buku...(hal. 240 - 259)

Dalam teks Tari Saman, ada 9 kata (regnum, dering, redet, sek, saur, guncang, kirep, lingang, dan surang-saring) dan 2 frasa (bulang teleng dan sunting kepies) yang berasal dari bahasa Gayo, sedangkan peserta tes asosiasi kata mayoritas berbahasa Jawa. Oleh karena itu, tingkat keterbacaan teks tentang Tari Saman sulit. Hal itu dibuktikan dengan skor yang dihasilkan mereka, yakni 146 atau $15 \%$.

\section{b. Input (Masukan)}

Masukan yang dimaksud adalah pengetahuan pembaca yang didasari oleh lingkungan pembaca dan informasi yang mereka peroleh dari media massa atau seminar. Berdasarkan hal itu, dideskripsikan masukan sebagai berikut.

\section{Lingkungan Pembaca}

a) Secara geografis, letak keempat sekolah tersebut jauh, $\pm 70 \mathrm{~km}$, dari laut sehingga tingkat keterbacaan teks tentang biota laut sulit. Hal tersebut dibuktikan dengan skor yang dihasilkan mereka, yakni 230 atau $24 \%$.

b) Secara geografis, letak keempat sekolah itu jauh, $\pm 3.200 \mathrm{~km}$, dari Aceh sehingga tingkat keterbacaan teks tentang Tari Saman sulit. Hal itu dibuktikan dengan skor yang dihasilkan mereka, yakni 146 atau 15\%.

c) Secara geografis, letak keempat sekolah tersebut jauh, $\pm 280 \mathrm{~km}$, dari Yogyakarta yang menjadi lokasi candi prambanan sehingga pengetahuan siswa tentang cerita candi prambanan sangat minim. Hal tersebut dibuktikan dengan skor yang dihasilkan mereka, yakni 57 atau $6 \%$.

\section{Informasi dari Media Massa atau Seminar}

a) Seminar atau pelatihan tentang pendidikan karakter di Mojokerto cenderung menyasar siswa SMP/SMA di Kota Mojokerto, misalnya seminar pendidikan karakter yang dilaksanakan di SMAN 3 Mojokerto pada Juli 2014 dan di SMPN 6 Mojokerto pada Mei 2014. Oleh karena itu, skor pengetahuan awal pembaca, siswa SMP se-Kabupaten Mojokerto, tentang remaja dan 
pendidikan karakter hanya 147 atau 15\% sehingga tingkat keterbacaan teks yang berhubungan dengan remaja dan pendidikan karakter sulit.

b) Sebelum tes asosiasi kata dilaksanakan, gempa bumi terjadi pada Mei s.d. Juli 2014 di Pacitan, Trenggalek, Tasikmalaya, Gorontalo, Sukabumi, dan Lampung. Dari enam daerah tersebut, Kabupaten yang terdekat dengan Kabupaten Mojokerto adalah Trenggalek. Jarak antara dua kabupaten tersebut adalah $\pm 158 \mathrm{~km}$. Gempa di kabupaten tersebut terjadi pada 24 Juli 2014. Jarak waktu kejadian dengan tes dan jarak antarkabupaten menyebabkan informasi yang diperoleh siswa tentang gempa bumi tidak banyak sehingga tingkat keterbacaan teks yang berhubungan dengan gempa bumi. Hal itu dibuktikan dengan skor tes, yakni 159 atau $17 \%$.

\section{Suku kata Memengaruhi Short-Term Memory dan Long-Term Memory}

Short-term memory atau ingatan jangka-pendek dan long-term memory atau ingatan jangka-panjang dipengaruhi oleh jumlah suku kata yang harus diingat. Memoru jangka-pendek cenderung menjaga konten kata demi kata, sedangkan memori jangka-panjang cenderung menjaga makna (Clark dan Clark, 1977:138). Dalam penelitian ini, jumlah rata-rata suku kata adalah 149,8 dari 7,67 kalimat sehingga tiap kalimat rata-rata 19,53 suku kata dengan level keterbacaan di level 7, 8, dan 9. Oleh karena itu, siswa kelas VII, VIII, dan IX berkecenderungan mengingat 19,53 suku kata per kalimat dalam memori jangkapendek. Berbeda dengan itu, Berdasarkan penelitian yang dilakukan Sachs's (Clark dan Clark, 1977:140), persentase makna yang sama dalam memori jangkapanjang setelah membaca teks tersebut adalah $70-75 \%$, sedangkan persentase makna yang berbeda dalam memori jangka-panjang setelah membaca teks tersebut adalah $80-85 \%$.

\section{Prosedur dan Kohesi Leksikal di Tes Cloze}

Perbedaan dan Persamaan Prosedur Tes Cloze

256 | ISSN: 22477-5150 http://journal.unesa.ac.id/index.php/jpi 
Ariesta Bagus Pramuwibowo, Keterbacaan Teks dalam Buku...(hal. 240 - 259)

Dalam penelitian ini, tidak digunakan prosedur umum tentang tes tersebut. Pertama, digunakan unsur kebahasaan yang harus diketahui siswa kelas VII sebagai unsur yang harus bisa dikontrol siswa tersebut, sedangkan dalam penelitian Handayani digunakan penghilangan kata ke-n. Kedua, Handayani meneliti teks berbahasa Inggris, sedangkan penelitian ini meneliti teks berbahasa Indonesia. Ketiga, subjek penelitian Handayani adalah kelas VIII, sedangkan penelitian ini adalah kelas VII.

Berbeda dengan itu, soal di penelitian ini dan penelitian Handayani sama, yakni 50 tiap tes. Tidak hanya itu, hasil tes Cloze penelitian ini dan penelitian yang dilaksanakan oleh Handayani hampir sama, yakni tingkat keterbacaan teks sulit karena persentase penelitian ini adalah 13\%, sedangkan penelitian Handayani adalah $24 \%$.

\section{Kohesi Leksikal di Tes Cloze}

Sebelumnya, belum ada penelitian keterbacaan yang menggunakan tes Cloze yang dimodifikasi dengan unsur kebahasaan sebagai acuan delisi tiap kata. Unsur kebahasaan yang paling banyak muncul adalah kohesi leksikal, yakni repetisi. Repetisi adalah bagian dari reiterasi (pengulangan). Reiterasi yaitu piranti kohesi yang digunakan dengan mengulang sesuatu proposisi atau bagian dari proposisi (Rani dkk., 2004:129).

Dalam penelitian ini, repetisi yang harus dikontrol oleh siswa adalah ulangan penuh dan ulangan dengan penggantian. Persentase skor tes Cloze berdasarkan unsur kebahasaan, yakni repetisi ulangan penuh adalah 35\%, sedangkan repetisi dengan penggantian adalah $28 \%$.

\section{SIMPULAN}

Dalam penelitian tersebut, tujuh ciri kalimat efektif yang digunakan untuk menganalisis kalimat dalam teks adalah kesepadanan struktur, keparalelan, 
ketegasan, kehematan, kecermatan, kepaduan, dan kelogisan. Berdasarkan hasil analisis, kalimat yang tidak efektif ada tiga belas. Kalimat tersebut tidak sesuai dengan kesepadanan struktur, keparalelan, kehematan, dan kecermatan. Ada 8 kalimat yang tidak sesuai dengan kesepadanan struktur, 6 kalimat yang tidak sesuai dengan keparalelan, 1 kalimat yang tidak sesuai dengan kehematan, dan 1 kalimat yang tidak sesuai dengan kecermatan. Jadi, dari 99 kalimat, ada 86 kalimat yang sesuai ciri kalimat efektif. Berdasarkan hal itu, persentase jumlah kalimat efektif adalah 87\%. Oleh karena itu, dinyatakan bahwa tingkat keterbacaan teks dalam buku BIWPrp adalah mudah karena siswa kelas VII mudah membaca teks dalam buku tersebut, khususnya siswa yang bersekolah di Kabupaten Mojokerto.

Tingkat keterbacaan teks berdasarkan pengetahuan pembaca didasarkan pada pengetahuan awal pembaca tentang topik dan kontrol kosakata yang dipengaruhi oleh pengetahuan kebahasaan pembaca. Berdasarkan dua hal itu ditemukan bahwa tingkat keterbacaan teks adalah sulit. Hal tersebut dibuktikan dengan hasil tes asosiasi kata (tes yang didasarkan pada pengetahuan awal pembaca tentang topik), yaitu $15 \%$. Bukti yang lain didasarkan pada tes Cloze (tes yang didasarkan pada kontrol kosakata yang dipengaruhi oleh pengetahuan kebahasaan siswa), yaitu 13\%. Dengan demikian, teks dalam buku BIWPrp sulit dibaca dan dipahami siswa kelas VII karena kualitas teks berdasarkan panjangpendek kata dan pengetahuan siswa (awal serta pengontrolan kata) tergolong sulit bagi siswa tersebut.

\section{DAFTAR RUJUKAN}

Gilliland, John. 1972. Readability. London: Holder and Stroughton.

Muchlisoh. 1996. Pendidikan Bahasa Indonesia 3. Jakarta: Depdikbud.

Ningsih, Sri dkk. 2007. Bahasa Indonesia untuk Mahasiswa. Yogyakarta: Penerbit Andi. 
Ariesta Bagus Pramuwibowo, Keterbacaan Teks dalam Buku...(hal. 240 - 259)

Peraturan Menteri Pendidikan Dan Kebudayaan Republik Indonesia Nomor 71 Tahun 2013 Tentang Buku Teks Pelajaran dan Buku Panduan Guru Untuk Pendidikan Dasar dan Menengah.

Pusat Perbukuan Nasional. 2003. Pedoman Pengembangan Standar Perbukuan. Jakarta: Departemen Pendidikan Nasional.

Zakulak, Beverley L. dan Samuels, S. Jay. 1988. Readability: "It Past, Present, and Future". Newark, Delaware: International Reading Association, Inc. 